Review Article

\title{
Predictive vision on governance and total quality in sports
}

\author{
Ibouchoukene Mohamed ${ }^{1}$, Aboura Rabah', Hadiouche \\ Abdelnour ${ }^{2}$, Labane Karim ${ }^{1 *}$ and Fahssi Mohamed Riadh ${ }^{1}$ \\ ${ }^{1}$ University of Algiers, Algeria \\ ${ }^{2}$ Institute of Physical Education and Sports, Algeria
}

\section{Summary}

The aim of our study is to try to give a predictive vision on governance in the field of sports in Algeria.

This predictive approach looks at the overall quality of governance in order to be at the continental level or even across the Arab world.

To identify this and answer our questions, we conducted a survey of some leaders of the different sports institutions, namely the presidents of clubs (football, handball, athletics and judo), managers also have a sports experience and occupy currently responsible positions as managers of sports facilities.

The results of the survey we reveal significant figures on the component related to sports development prospects.

However, there are other aspects that are ambiguities in the management and organization that have an impact on good governance in sports.

\section{Introduction}

The issue of governance in sport in Algeria, was always at the heart of concerns. It therefore continues to challenge scientists and managers to optimize the management and supervision of the sport whose aim is to achieve good governance of the Algerian sports movement.

The purpose of this research focuses on the question of total quality management and sports organization in the different structures and sports institutions of the state.

Note that these two parameters affect the nature of sports governance. For example, to solve the problem of relational management financially, reduce cost and increase market shares to grow the capital of shareholders, would be one of our initiative to offer [5].

There is also the know-how and competitiveness across globalization represents the true image of the sport governance. Lots of research has been done in the field of governance in general and in sport in particular.

Therefore challenged the sport governance are multiple

\section{More Information}

*Address for Correspondence: Labane Karim, University of Algiers, Algeria, Tel: 2130666607816; Email: labakarim@yahoo.fr

Submitted: 01 November 2018

Approved: 12 July 2019

Published: 15 July 2019

How to cite this article: Mohamed I, Rabah A, Abdelnour H, Karim L, Riadh FM. Predictive vision on governance and total quality in sports. $\mathrm{J}$ Sports Med Ther. 2019; 4: 046-049. doi:10.29328/journal.jsmt.1001042

Copyright: (c) 2019 Mohamed l, et al. This is an open access article distributed under the Creative Commons Attribution License, which permits unrestricted use, distribution, and reproduction in any medium, provided the original work is properly cited

Keywords: Sport governance; Total quality; Management and sports organization

Check for updates since the past decade. A number of issues emerge filigree: how decisions are made in sports organizations?

How are influenced by the government, politically, economically and socially?

What are the effects of modes of governance on the management styles that affect the profitability sports?

Who should lead, manager, control? [3].

\section{Theoretical approach on sports governance}

Sports governance, management structures and sports bodies are affected by good control of the sport, and especially the flow of ideas raised in the sports project, to provide a longterm vision.

Bayle E and Chantelat $\mathrm{P}$, talk about the governance of organizations, then this is the mastery of information that allows managers to handle situations in different structures, and many take the necessary measures to provide products and more ideas, take decisions to organize and give a promising sports management [3]. 
And to know how governance provides a good sports organization, we can say that there is a possibility to structure the projects and ideas of people manage their decisions. Are these decisions are influenced by the government? Is it another thought or another way to fit well the understanding between groups managing situations sporting events.

Chaker AN, cites that "Governance, the sport in particular can be defined in several ways. It can be, according to the people, referred to different meanings, especially if one takes a global perspective.

Sports governance is the establishment of effective networks of national sports agencies, non-governmental sports organizations and procedures that operate jointly and independently under the laws, policies and specific rules for private promoting ethical sporting, democratic, efficient and transparent"[4].

We can say that the data cited by several others in the field of sports marketing that allow officials to govern the structures that arise on a well-built platform, and above which contains a rigorous strategy called true.

The viability of the Algerian sports model is in play in all countries that manage effectively their sport in all disciplines, mass sport as elite sport are dependent on two major instances resources.

Public authorities and fans of the sport. Neither of these two groups could support a continuing degradation level sport governance in the future. In another context, the sports organization and management of sports facilities could be influenced by good or bad governance.

We note, moreover, that globalization requires some political strategy based on well considered decisions.

Hums [7], Mrs. A and others, offer coherent reflection on the political condition for good governance of sports organizations based on good policy decision like the following:

- Help to master the fundamentals of governance and conduct policies of these organizations;

- Expose the mechanisms inherent to networks that develop in the international sports area: how each interacts with other sports organization and where decisions take?

- Contextualise relations between sports organizations and political power;

- Ensuring identify specific models of global governance by showing the similarities and differences in a globalized sports world ... [6].

Total quality, good references for sport governance

Good governance in sport, it is the quality of management and organization of human and material resources with the requirements of sport, national or international.

And to choose a good management and good sports organization, you have to properly structure the actors in sport or federations, leagues and clubs, to refer to the conditions of the application of total quality in the known sport globally.

Ishikawa $\mathrm{K}$, speaks good sports management in a very interesting way, but we must know the rules of the practice of field data, and for that we must define the conditions for the application of total quality [7].

Total quality is a reference model for a good sports management then you have to put in evidence the expectations of the sports population, officials, practitioners or supporters, and there can say we are on the right track by compared to total quality data [1].

Bannker $\mathrm{S}$ and Majer $\mathrm{H}$, have given the system for applying total quality measures adapted to the sports organization and especially for sport governance. These measures are as follows:

- Sports administration officials, who give the programs and projects of sport, must create a policy to implement a true total quality.

- The objectives of their sports governance must realize the reality on the ground.

- The scientific work in the field of sports governance are references and bases to adopt a total quality policy.

- The administration of human and material resources, is the important basis that characterizes the competition to a good sports governance at the national and international levels [2].

Focus on the methodological Framework and discussion of results.

\section{Materials and Methods}

\section{Topics}

To the tasks of our work we have carried out our investigations on forty (40) leaders and leaders of clubs (football, handball, athletics and judo) or twenty (20) heads of federations and leagues, and twenty (20) leaders of elite clubs. Sample characteristics are shown in table 1.

\begin{tabular}{|c|c|c|}
\hline Table 1: Sample characteristics. & \\
\hline Elected & +03 times & Diregents clubs \\
\hline $\mathrm{N}$ & 20 & +03 times \\
\hline Management general & $25 \%$ & 20 \\
\hline Sport management & $15 \%$ & $45 \%$ \\
\hline Age & $56.17 \pm 0.89$ & $88.50 \%$ \\
\hline President & $1.67 \pm 0.70$ & $53.89 \pm 1.39$ \\
\hline General secretary & $1.41 \pm 1.31$ & $2.34 \pm 1.63$ \\
\hline Member & $13.36 \pm 1.19$ & $372 \pm 1.97$ \\
\hline
\end{tabular}




\section{Equipment}

We used the following search engines:

- A questionnaire to member leagues.

- An interview for the presidents of federations and clubs.

\section{Method of investigation}

Analytical descriptive method: This is the most appropriate method in this kind of study primarily to restore the data and consult with a questionnaire and interview with a member of the sampling.

\section{Statistical method}

The method used is the parametric statistics [6], which allows the characterization and cut the population and more specifically the series of values of a variable that includes using as the arithmetic average parameters (which is determined by the sum of the observed values divided by the number of series elements); variance and coefficient of variation:

$$
\bar{x}=\frac{1}{n} \sum_{i=1}^{n} x_{i}
$$

As it is very important to know how it is that the group is arranged around the middle it is grouped or scattered around it. The standard deviation is a dispersion index because it provides information on the dispersion around the mean. We calculate the standard deviation of the sample by using the following formula:

$\sigma=\sqrt{\frac{\sum(x-\bar{x})^{2}}{n-1}}$

$\neg$ For analytical statistics was used Student test, to calculate the difference of means of two samples.

$\neg$ And to all our calculations (mean, standard deviation and T Student) we used the Office Excel 2007 software.

\section{Results}

Table 2 Questionnaire Results.

Table 3 Comparative analysis of the responses of federal officials and leagues with those of club leaders.

\section{Discussion}

The analysis of the results of the sports organization settings made on our sample, we find that there is only three (03) significant differences (in various sporting events, references to known models, make decisions ...).

\begin{tabular}{|c|c|c|}
\hline & Officials fed / lig & Diregents clubs \\
\hline Sports management & Yes or no & Yes or no \\
\hline Yes & $17.77 \pm 2.52$ & $19.89 \pm 0.02$ \\
\hline References to standards & $6.05 \pm 0.71$ & $3.13 \pm 0.88$ \\
\hline adapted & $3.37 \pm 0.21$ & $0.52 \pm 0.20$ \\
\hline decisions & $15.73 \pm 0.70$ & $19.72 \pm 0.36$ \\
\hline With vote & $8.5 \pm 5.73$ & $3.22 \pm 4.38$ \\
\hline Others & $0.94 \pm 0.32$ & $1.74 \pm 0.59$ \\
\hline
\end{tabular}

Table 3: Comparative analysis of the responses of federal officials and leagues with those of club leaders.

\begin{tabular}{|c|c|}
\hline Test & T Student \\
\hline Number & $50 \%$ \\
\hline Self governance & 0.23 \\
\hline Decisions by vote & $\mathrm{S}^{\star}$ at 0.05 \\
\hline Always & $\mathrm{S}^{\star} 2.13$ \\
\hline By references to standars & $\mathrm{S}^{\text {at }} \mathrm{p}<0.05$ \\
\hline Never & $\mathrm{S}^{\star \star}$ at 0.01 \\
\hline With model & N.S at 0.05 \\
\hline Polytiques decisions & N.S at 0.05 \\
\hline View of ISO standars & N.S at 0.05 \\
\hline Others & $S^{\star \star}$ at 0.01 \\
\hline
\end{tabular}

NS: no significant difference, *difference significant at $p<0.05$, ** significant difference $p<0.01, \star \star \star$ significant difference at $p<0.001$

For the sports management: there are no significant differences between the leaders of federations and leagues and club leaders for a threshold of 0.05 .

For personal decisions we note that there are significant differences between the two samples to a threshold of 0.05 .

As for the comparison of answers about the interview questions, we see that very significant differences exist $\left(\mathrm{S}^{* *}\right)$ regarding the response rate seen as iso benchmark management and sports organization $\left(5^{*} 12\right)$ for a threshold of 0.01 , the rest was found significant difference.

Regarding the sample of members or in sports facilities or clubs, we have made a non-influenced data collection by comparing only the mean and standard deviation for each group, and given the small number of group club members) against nine (09) in known structures.

There by calculating the Student's t could not be made. They are represented as follows:

- That there is no significant difference in total a sports organization settings \% between them is very small.

- That there is no significant difference in sport management capabilities but we see that the club presidents shifts a non reduced rate.

- That $\mathrm{n}$ is not an effort to put sports structures to ISO standards approaching total quality.

\section{Conclusion}

As part of our thinking, we well informed as sport governance is related to the requirements of the conditions of total quality, with reference to international rules of global structures such as federations and sports clubs.

And to establish the combination of good sports management and organization structures that manage or apply the decision and plots programs, we found in our country, few officials give a true professional dimension to the sports management Algerian, but after consulting some officials and leaders we can hope that there is a political will in whatever federations or liege and sports clubs. 
Finally, we can say that the sport governance is linked to two main points: the specialists in sports management and policy-making officials.

\section{References}

1. Gogue JM. Qualité totale et plus encore. Ed l'harmattan, paris, 2006.

2. Bayle E, Etchantelat P. La gouvernance des organisations sportives. Edition l'harmattan. Paris. 2008.

3. Chaker AN. la route vers une meilleur gouvernance du sport 1 . Voir
André Noël Chaker, Good Governance in Sport: A European Survey, Council of Europe Publishing. 2004.

4. Ishikawa K. La gestion de la quality: Outils et applications pratiques. Ed DUNOD, France, 2007

5. Hums MA. et autres, La gouvernance au cœur des politiques des organisations sportives, De boeck, Bruxelles, 2011.

6. Adreaensens B. et autres, Marketing et qualité totale. Ed De boeck, Bruxelles, 1993

7. Majer B. Total quality management in high education. 2nd ed Putnam publishing group, New york. 